\title{
Valuing Transit Service Quality Improvements
}

Todd Litman, Victoria Transport Policy Institute

\begin{abstract}
This article investigates the value transit travelers place on qualitative factors, such as comfort and convenience, and practical ways to incorporate these factors into transport planning and project evaluation. Conventional evaluation practices generally assign the same time value regardless of travel conditions, and so undervalue comfort and convenience impacts. More comprehensive analysis of transit service quality tends to expand the range of potential transit improvement options, and justify more investments in transit service quality improvements. This article examines the value passengers place on transit service quality, summarizes research on travel time valuation, explores how transit service quality factors affect travel time values and transit ridership, and discusses implications of this analysis.
\end{abstract}

\section{Introduction}

Albert Einstein once illustrated the relativity of time by saying, "When a man sits with a pretty girl for an hour, it seems like a minute. But let him sit on a hot stove for a minute and it's longer than any hour." Similarly, a minute spent in unpleasant conditions waiting for a bus may seem like an hour, while an hour spent working, resting, or conversing while traveling on a comfortable bus or train may seem pleasant or even delightful.

Qualitative factors such as travel convenience, comfort, and security affect travel time unit costs, the value users assign to their travel time, measured in cents per 
minute or dollars per hour. Various studies summarized in this article indicate that inconvenience and discomfort often double or triple average travel time costs. This has important implications for transportation planning since travel time costs are a major factor in transport project evaluation. How travel time is measured can significantly affect planning decisions.

Unfortunately, conventional planning practices tend to overlook and undervalue service quality impacts. The indicators used to identify transportation problems (such as roadway level-of-service ratings) and the models used to evaluate potential transport improvements focus on quantitative factors (speed, operating costs, and crash rates), and ignore qualitative factors (convenience, comfort, and prestige).

This is particularly important for transit planning because transit service quality varies from awful to good, and sometimes even delightful, and because nearly all transit service quality decisions are made in a formal planning process. A motorist who values convenience and comfort can pay extra for a vehicle with features such as automatic navigation systems, extra comfortable seats, optional safety equipment, sophisticated sound systems, and even heated cupholders. On the other hand, public transit is usually provided as a basic level of service. It is not usually possible to pay extra for higher quality service, such as a nicer waiting area or a less crowded vehicle. Such service quality improvements are made only if planners are able to demonstrate their value.

These omissions undervalue many cost-effective transit service improvements, such as more comfortable vehicles, reduced crowding, nicer stations, improved walkability, better user information, improved security, and marketing and promotion. Improving transit service quality:

- benefits existing transit passengers (who would use transit even without the improvements);

- benefits new transit passengers (who would only use transit if service is improved);

- benefits society by reducing traffic problems (congestion, roadway and parking costs, consumer costs, accidents, energy consumption, and pollution emissions);

- provides scale economies (increased ridership can create a positive feedback cycle of improved service, increased public support, more transit-oriented land use, and further ridership increases); and

- benefits transit agencies by increasing fare revenue. 
This article investigates the value passengers place on transit service quality, summarizes research on travel time valuation, examines how transit service quality factors affect travel time values, discusses implications of this analysis, and recommends additional research. This information should be useful for planners interested in finding cost-effective ways to improve transit service and increase transit ridership.

\section{Quantifying Travel Time Values}

Numerous studies have quantified and monetized (measured in monetary units) travel time costs (Mackie et al. 2003; Wardman 2004). Travel time unit costs are generally calculated relative to average wages, with variations reflecting different factors discussed below (Waters 1992; Litman 2006).

- Commercial (paid) travel costs should include driver wages and benefits, and the time value of vehicles and cargo reflecting efficient use of assets and ability to meet delivery schedules.

- Personal (unpaid) travel time unit costs are usually estimated at 25 to 50 percent of prevailing wage rates.

- Travel time costs tend to be higher for uncomfortable, unsafe, and stressful conditions (Brundell-Freij 2006).

- Travel time costs tend to increase with income, and tend to be lower for children and people who are retired or unemployed (put differently, people with full-time jobs usually have more demands on their time and so tend to be willing to pay more for travel time savings).

- A moderate amount of daily travel often has little or no time cost, since people generally seem to enjoy a certain amount of daily travel (Mokhtarian 2005). Recreational travel and errands that involve social activities often have minimal cost or positive value.

- Unit time costs tend to increase if trips exceed about 20 minutes in duration or total personal travel exceeds about 90 minutes per day.

- Travel time costs increase with variability and arrival uncertainly (Cohan and Southworth 1999), and tend to be particularly high for unexpected delays (Small et al. 1999).

- Walking and waiting time unit costs are two to five times higher than in-vehicle transit travel time (Pratt 1999, Table 10-12). Transfers tend to 
impose extra costs (called a transfer penalty) due to the additional effort they require, typically equivalent to 5 to 15 minutes of in-vehicle travel time (Horowitz and Zlosel 1981; Evans 2004).

- Under pleasant conditions walking, cycling, and waiting can have low or positive value, but under unpleasant conditions (walking along a busy highway or waiting for a bus in an area that seems dirty and dangerous) their costs are significantly higher than in-vehicle time.

- People have diverse mobility needs and preferences, so improved options allows individuals to choose the best one for each trip. For example, some people prefer driving while others prefer transit travel; having both available allows people to select the option that minimizes costs, including travel time costs, and maximizes benefits (Novaco and Collier 1994).

The following two factors are particularly important for analysis in this article:

1. Transit travel conditions, and therefore transit travel time unit cost values, are extremely variable. Under pleasant conditions (comfortable, clean, quiet, and safe vehicles and waiting areas), transit travel time unit costs are lower than driving because passengers experience less stress and are able to rest or use their time productively. However, if transit conditions are unpleasant, transit travel times are significantly higher than automobile travel.

2. In most communities a portion of transit travelers are captive-people who are unable to drive and so are forced to use transit regardless of service quality. However, transit will only attract discretionary travelers (those who could drive for a particular trip, also called choice riders) if high service quality reduces unit travel time costs relative to automobile travel.

These factors have significant implications for transit project evaluation, as summarized in Table 1. More accurate analysis of these impacts tends to increase the recognized costs of degraded transit service quality, and increase the recognized benefits of transit service quality improvements.

Li (2003) describes how these factors tend to favor automobile commuting:

An auto commute is attractive in most courses of perceived travel time, compared to a public transportation commute. It is most likely a door-to-door service, thus minimizing the number of commute stages [transfers]. It spends time predominantly on the ride episode, usually with seats secured and even entertainment (e.g., music) of the commuter's choice. It demands the 
Table 1. Factors Affecting Travel Time Costs

\begin{tabular}{|c|c|c|}
\hline Factor & Description & Transit Evaluation Implications \\
\hline Waiting & $\begin{array}{l}\text { Waiting time is usually valued higher } \\
\text { than in-vehicle travel time. }\end{array}$ & $\begin{array}{l}\text { Transit travel usually requires more waiting, } \\
\text { often along busy roads, with little protection. }\end{array}$ \\
\hline Walking links & $\begin{array}{l}\text { Time spent walking to vehicles is usually } \\
\text { valued higher than in-vehicle travel time. }\end{array}$ & $\begin{array}{l}\text { Transit travel usually requires more walking } \\
\text { for access. }\end{array}$ \\
\hline Transfers & Transfers impose a time cost penalty. & Transit travel often requires transfers. \\
\hline Trip duration & $\begin{array}{l}\text { Unit costs tend to increase for trips that } \\
\text { exceed about } 40 \text { minutes. }\end{array}$ & $\begin{array}{l}\text { Transit travel tends to require more time than } \\
\text { automobile travel for a given distance. }\end{array}$ \\
\hline $\begin{array}{l}\text { Unreliability (travel } \\
\text { time variance) }\end{array}$ & $\begin{array}{l}\text { Unreliability, particularly unexpected } \\
\text { delays, increase travel time costs. }\end{array}$ & $\begin{array}{l}\text { Varies. Transit is often less reliable, except } \\
\text { where given priority in traffic. }\end{array}$ \\
\hline $\begin{array}{l}\text { Waiting and vehicle } \\
\text { environments }\end{array}$ & $\begin{array}{l}\text { Uncomfortable conditions (crowded, } \\
\text { dirty, insecure, cold, etc.) increase costs. }\end{array}$ & $\begin{array}{l}\text { Transit travel is often less comfortable than } \\
\text { private vehicle travel. }\end{array}$ \\
\hline Sense of control & $\begin{array}{l}\text { A person's inability to control their } \\
\text { environment tends to increase costs. }\end{array}$ & $\begin{array}{l}\text { Transit travel is often perceived as providing } \\
\text { little user control. }\end{array}$ \\
\hline $\begin{array}{l}\text { Cognitive effort (need } \\
\text { to pay attention) }\end{array}$ & $\begin{array}{l}\text { More cognitive effort increases travel } \\
\text { time costs. }\end{array}$ & $\begin{array}{l}\text { Varies. Driving generally requires more effort, } \\
\text { particularly in congestion. }\end{array}$ \\
\hline Variability & $\begin{array}{l}\text { Transit travel conditions are extremely } \\
\text { variable, depending on the quality of } \\
\text { walking, waiting, and vehicle conditions. }\end{array}$ & $\begin{array}{l}\text { Transit benefit analysis is very sensitive to } \\
\text { qualitative factors that currently tend to be } \\
\text { overlooked and undervalued. }\end{array}$ \\
\hline $\begin{array}{l}\text { Captive vs. } \\
\text { discretionary travelers }\end{array}$ & $\begin{array}{l}\text { Some transit users are captive and so } \\
\text { relatively insensitive to convenience and } \\
\text { comfort, but discretionary travelers tend } \\
\text { to be very sensitive to these factors. }\end{array}$ & $\begin{array}{l}\text { Achieving automobile-to-transit mode shifts } \\
\text { requires comprehensive analysis to identify } \\
\text { service quality factors that attract } \\
\text { discretionary travelers. }\end{array}$ \\
\hline
\end{tabular}

Source: Pratt 1999; Li 2003; Litman 2006.

commuter's (i.e., driver's) continuous attention to road conditions and motor operation, rather than temporal cues or information, and hence exploits the cognitive resource for nontemporal information processing. Also, it avoids the temporal and monetary losses due to unreliable public transportation services. All these may result in a given journey perceived as shorter for an auto commute, and hence the commute experience to be more positively evaluated than for a commute with public transportation.

However, under optimal conditions transit travel can have lower unit time costs than driving, particularly if travelers can select the mode that best meets their needs and preferences. A survey of New Jersey commuters found that train users experienced less stress and fewer negative moods than drivers making similar trips, indicating the reduced effort and greater predictability of train travel (Wener, Evans, and Lutin 2006). Train commuter stress levels declined significantly after service improvements reduced their need to transfer. 
A survey of U.K. rail passengers found that many use their time for productive activities such as working or studying (30\% some of the time and $13 \%$ most of the time), reading ( $54 \%$ some of the time and $34 \%$ most of the time), resting ( $16 \%$ some of the time and $4 \%$ most of the time), and talking to other passengers (15\% some of the time and $5 \%$ most of the time), and so place positive utility on such time (Lyons, Jain, and Holley 2007). When asked to rate their travel time utility, 23 percent indicated that "I made very worthwhile use of my time on this train today," 55 percent indicated that "I made some use of my time on this train today," and 18 percent indicated that "My time spent on this train today is wasted time." The portion of travel time devoted to productive activity is higher for business travel than for commuting or leisure travel, and increases with journey duration.

\section{Service Quality Valuation}

The value transit users (and potential users) place on service quality can be measured using stated preference surveys (which ask people how much they value a particular feature) and revealed preference studies (which evaluate the choices people actually make when facing trade-offs between various attributes). One example of this type of analysis is described below.

Research for RailCorp (an Australian rail company) surveyed train riders to assess the value they place on various service attributes. Table 2 summarizes vehicle service values, measured by the additional fares or time travelers would willingly bear in exchange for a 10 percent improvement (from $50 \%-60 \%$ acceptability ratings). For example, travelers indicated that they would willingly pay $5.6 \mathrm{c}$ per minute or tolerate a 0.38 -minute increase in onboard travel times in exchange for such a 10point improvement in train layout and design.

Table 3 presents the additional fare or onboard time train travelers would be willing to pay for a 10 percent improvement of various station attributes. For example, travelers expressed willingness to pay $2.4 \mathrm{c}$ per minute or tolerate a 16 -minute increase in their onboard travel times in exchange for such a 10-point improvement in train layout and design. 
Table 2. Value of Train Improvements

\begin{tabular}{|l|c|c|}
\hline \multicolumn{1}{|c||}{ Type of Train Improvement } & $\begin{array}{c}\text { Additional Fares } \\
\text { (2003 Aust. Cents } \\
\text { per Minute) }\end{array}$ & $\begin{array}{c}\text { Additional Onboard Time } \\
\text { (Additional Time } \\
\text { in Minutes) }\end{array}$ \\
\hline Layout and design improvements & $5.6 \phi(2.2 \%)$ & $0.38(1.0 \%)$ \\
\hline Cleanliness & $3.8 \phi(1.5 \%)$ & $0.26(0.7 \%)$ \\
\hline Ease of train boarding & $3.2 \phi(1.2 \%)$ & $0.22(0.6 \%)$ \\
\hline Quietness & $3.2 \phi(1.2 \%)$ & $0.22(0.6 \%)$ \\
\hline Train outside appearance & $2.3 \phi(0.9 \%)$ & $0.15(0.4 \%)$ \\
\hline On-train announcements improved & $2.3 \phi(0.9 \%)$ & $0.16(0.4 \%)$ \\
\hline Heating and air-conditioning & $2.2 \phi(0.8 \%)$ & $0.15(0.4 \%)$ \\
\hline Improved lighting & $1.9 \phi(0.7 \%)$ & $0.13(0.4 \%)$ \\
\hline Smoothness of ride & $1.5 \phi(0.6 \%)$ & $0.10(0.3 \%)$ \\
\hline Graffiti removed & $1.2 \phi(0.5 \%)$ & $0.08(0.2 \%)$ \\
\hline Seat comfort & $1.1 \phi(0.4 \%)$ & $0.07(0.2 \%)$ \\
\hline
\end{tabular}

Source: Douglas Economics 2006.

Table 3. Value of Station Improvements

\begin{tabular}{|l|c|c|}
\hline \multicolumn{1}{|c|}{ Type of Station Improvement } & $\begin{array}{c}\text { Additional Fares } \\
\text { (2003 Aust. Cents } \\
\text { per Minute) }\end{array}$ & $\begin{array}{c}\text { Additional Time } \\
\text { (Increased Onboard Time } \\
\text { in Minutes) }\end{array}$ \\
\hline Tickets & $2.4 \phi(0.9 \%)$ & $16(43.2 \%)$ \\
\hline Cleaning & $1.9 \phi(0.7 \%)$ & $13(35.1 \%)$ \\
\hline Station building & $1.4 \phi(0.5 \%)$ & $10(27.0 \%)$ \\
\hline Staff & $1.3 \phi(0.5 \%)$ & $9.0(24.3 \%)$ \\
\hline Ease of train on and off & $1.1 \phi(0.4 \%)$ & $8.0(21.6 \%)$ \\
\hline Platform surface & $1.0 \phi(0.4 \%)$ & $7.0(18.9 \%)$ \\
\hline Station announcements & $0.8 \phi(0.3 \%)$ & $5.0(13.5 \%)$ \\
\hline Safety & $0.8 \phi(0.3 \%)$ & $6.0(16.2 \%)$ \\
\hline Signing & $0.7 \phi(0.3 \%)$ & $5.0(13.5 \%)$ \\
\hline Graffiti & $0.7 \phi(0.3 \%)$ & $5.0(13.5 \%)$ \\
\hline Retail & $0.7 \phi(0.3 \%)$ & $5.0(13.5 \%)$ \\
\hline Platform seating & $0.6 \phi(0.2 \%)$ & $4.0(10.8 \%)$ \\
\hline Lifts/escalators & $0.4 \phi(0.2 \%)$ & $3.0(8.1 \%)$ \\
\hline Information & $0.4 \phi(0.2 \%)$ & $3.0(8.1 \%)$ \\
\hline Station lighting & $0.4 \phi(0.2 \%)$ & $3.0(8.1 \%)$ \\
\hline Bus & $0.3 \phi(0.1 \%)$ & $2.0(5.4 \%)$ \\
\hline Bike & $0.3 \phi(0.1 \%)$ & $2.0(5.4 \%)$ \\
\hline Toilets & $0.2 \phi(0.1 \%)$ & $1.0(2.7 \%)$ \\
\hline Car park & $0.2 \phi(0.1 \%)$ & $1.0(2.7 \%)$ \\
\hline Car park drop-off & $0.2 \phi(0.1 \%)$ & $1.0(2.7 \%)$ \\
\hline Platform weather protection & $0.1 \phi(0.0 \%)$ & $0.4(1.1 \%)$ \\
\hline Subway/overbridge & $0.1 \phi(0.0 \%)$ & $0.1(0.3 \%)$ \\
\hline Taxi & $0.1 \phi(0.0 \%)$ & $0.1(0.3 \%)$ \\
\hline Telephone & $0.1 \phi(0.0 \%)$ & $0.1(0.3 \%)$ \\
\hline & &
\end{tabular}

Source: Douglas Economics 2006. 
Riders were also surveyed concerning their perceived cost of crowding. Crowded seating increases travel time costs by 17 percent, as shown in Table 4. Thus, 20 minutes of crowded seating would increase the generalized journey time by 3.4 minutes $(20 \times 0.17)$. In dollar terms, crowded seating adds $2 c$ per minute if time is valued at $\$ 9.46 / \mathrm{hr}$.

Table 4. Value of On-Train Crowding

\begin{tabular}{|l|c|c|}
\hline \multicolumn{1}{|c|}{ Crowding } & $\begin{array}{c}\text { Crowding Cost } \\
\text { (2003 Aust. Cents per Minute) }\end{array}$ & $\begin{array}{c}\text { Crowding Factor } \\
\text { (Additional Time) }\end{array}$ \\
\hline Crowded seat & $2.0 \notin$ & $17 \%$ \\
\hline Stand 10 mins or less & $5.0 \phi$ & $34 \%$ \\
\hline Stand 20 mins or longer & $11 \notin$ & $81 \%$ \\
\hline Crush stand 10 mins or less & $11 \notin$ & $104 \%$ \\
\hline Crush stand 20 mins or longer & $17 \dot{\phi}$ & $152 \%$ \\
\hline
\end{tabular}

Source: Douglas Economics 2006.

Crowding factors were expressed as a function of train passenger load factors (passengers divided by seats). Below an 80 percent load factor ( 80 passengers per 100 seats) no crowding costs are incurred. At 80 percent, crowding begins to impose costs. At 100 percent, the additional crowding factor is 0.1 , increasing onboard travel time unit costs by 10 percent, from $14.08 c$ per minute (the uncrowded seating value of time) to $15.49 \mathrm{c}$ per minute, an increase of $1.41 \mathrm{c}$ per minute. Loads of 160 percent add an additional crowding factor of 0.6 minutes or 8.45 c. At 200 percent loading (the maximum number of passengers CityRail trains are considered to be able to carry), the additional crowding factor is 0.74 or $10.43 \mathrm{c}$ per minute. Above 200 percent, passengers must wait for another train.

The UK Passenger Demand Forecasting Council reached similar conclusions concerning the costs of passenger discomfort and delay (PDFC 2002). The PDFC recommends that train load factors of 1.20 to 1.40 (120-140 passengers per 100 seats) result in crowding factors of 0.14 to 0.26 , compared with a 0.17 crowding factor calculated for Sydney (Douglas Economics 2006).

Crowding in accessways, stations, and platforms makes walking and waiting time less pleasant. Table 5 indicates adjustment factors for low, medium, high, and very high crowding conditions. A minute of time spent waiting under high crowding conditions is valued at 3.2 minutes of onboard train time whereas walking time is valued at 3.5 times higher (reflecting the additional discomfort and effort involved, but not the reduced walking speed caused by crowding). 
Table 5. Value of Platform Waiting and Access Time

\begin{tabular}{|l|c|c|c|c|}
\hline \multicolumn{1}{|c|}{ Activity } & \multicolumn{4}{|c|}{ Crowding Level } \\
\hline & $\begin{array}{c}\text { Low } \\
(<0.2 \text { PSM })\end{array}$ & $\begin{array}{c}\text { Medium } \\
(\mathbf{0 . 2}-\mathbf{0 . 5} \text { PSM })\end{array}$ & $\begin{array}{c}\text { High } \\
(\mathbf{0 . 5 - 2} \text { PSM })\end{array}$ & $\begin{array}{c}\text { Very High } \\
(>2 \text { PSM })\end{array}$ \\
\hline Waiting vs. onboard train time factor & $190 \%$ & $150 \%$ & $320 \%$ & $550 \%$ \\
\hline Walking vs. onboard train time factor & $220 \%$ & $220 \%$ & $350 \%$ & $620 \%$ \\
\hline Waiting value of time (2003 AUS/hr) & $\$ 18.30$ & $\$ 14.20$ & $\$ 30.30$ & $\$ 51.90$ \\
\hline Walking value of time (2003 AUS/hr) & $\$ 21.00$ & $\$ 21.00$ & $\$ 32.70$ & $\$ 58.90$ \\
\hline
\end{tabular}

PSM = Passengers per square meter.

Source: Douglas Economics 2006.

Fruin developed six station environment crowding levels-of-service (LOS) ratings, ranging from $A$ (no crowding) to $F$ (extreme crowding). These costs begin to increase significantly when crowding exceeds LOS D, which occurs at a density of 0.7 passengers per square meter (PSM). Crowding has an even greater impact on walking, since it both increases costs per minute and reduces walking speeds. Level of service $F$, characterized by the breakdown of passenger flow, imposes crowding costs 10 times greater than level of service $A$.

In some situations, increased crowding costs may reduce the benefits of other transit improvements or incentives that increase peak-period ridership. For example, transit fare reductions or improved rider information may increase ridership, increasing crowding costs. These additional costs should be considered when evaluating such strategies.

\section{Valuing Transit Passenger Information Improvements}

Transit user information includes bus stop signs, printed and posted schedules, conventional and automated telephone services, transit websites (including websites designed to accommodate cellular telephones and PDAs), changeable signs or monitors at stations and stops, and announcements. Some newer systems use real-time information on the location of individual buses and trains, so signs, monitors, and websites can predict when the next vehicle will arrive at a particular stop or destination.

Many transit systems now offer real-time information (Infopolis 2 Consortium 2000; CIty-VITAlity-Sustainability 2006). This information reduces waiting stress and allows passengers to better use their time and coordinate activities (Turnbull and Pratt 2003). Dziekan and Vermeulen (2006) evaluated the effects real-time 
information has on tram passenger perceived wait time, feelings of security, and use in The Hague, the Netherlands. One month before, 3 months, and 16 months after implementation, the same sample of travelers completed a questionnaire. The researchers found that perceived wait time decreased by 20 percent and noted no effects on perceived security and ease of use.

Turnbull and Pratt (2003) tested real-time information signs in 1984 at several platforms on the London Underground Northern Line. The signs gave order of arrival information for the next three trains, route and terminal destination, and the number of minutes before expected arrival. The previous signs had supplied the first two of these elements of information, but not predicted arrival time. Passenger value these systems: 95 percent of respondents indicated it was useful and 65 percent reported it helped reduce waiting uncertainty. The information was used by 12 percent to select what train to take, with passengers reporting that they employed the time until arrival in selecting transfer points or choosing to wait for a close behind train that might be less crowded.

\section{Travel Time Valuation Summary}

This analysis indicates that if transit service is convenient and comfortable, unit transit travel costs are lower than for driving, since transit travelers experience less stress and can use their time to rest or work. Under such conditions, transit travel time is typically valued at 25 to 35 percent of prevailing wages, compared with 35 to 50 percent for drivers. However, disamenities such as crowding, noise, and dirt significantly increase travel time unit costs. For example, transit travel time can be valued at about 25 percent of wage rates when sitting, 50 percent of wages when standing, 100 percent of wages in a crowded bus or train, and 175 percent of wages when waiting under unpleasant conditions, such as an unsheltered bus stop adjacent to a busy roadway.

Increased transit travel speeds can be valued based on average time costs, but improvements in reliability should be valued at a higher rate, reflecting the higher unit costs of unexpected delay. Each minute of delay beyond the published schedule should be valued at three to five times the standard in-vehicle travel time (perhaps excepting a two- or three-minute grace period considered to be a "normal" delay). 
Time spent walking to and waiting for transit vehicles generally has unit costs averaging two to five times higher than in-vehicle time, or 70 percent to 175 percent of prevailing wages. Improved walking and waiting conditions, such as transit area pedestrian improvements, and improved transit stop area cleanliness and security, reduces these relatively high unit costs, such as from 175 percent down to 70 percent of wage rates (from the higher to the lower end of the typical estimated cost range of these activities) or even lower, to 50 percent of wage rates if conditions are particularly pleasant, such as at an attractive transit station with real-time information, shops and services, and other convenience features. Although the value of travel time is generally lower for children than for adults, reflecting the lower opportunity cost of their time, discomfort should be valued at the same rate as adults or even higher. For example, under poor waiting conditions children's time should probably be valued at 175 percent of wage rates, or even greater, the same value applied to adult travelers under the same conditions, reflecting adults concern for their children's comfort and security.

Transfers are estimated to impose penalties equivalent to 5 to 15 minutes of invehicle time. This implies, for example, that a typical passenger would choose a 40-minute transit trip over a 30-minute trip that requires a transfer. This premium reflects the physical and mental effort involved, plus the relative discomfort and insecurity at a typical transit stop or station, and so may be reduced with more comfortable waiting conditions and better user information.

Table 6 illustrates "default" travel time unit cost values. These values are calculated relative to prevailing wages, adjusted to reflect LOS ratings. Roadway LOS rates are widely used for evaluating automobile travel conditions. In recent years similar rating systems have been developed for walking, cycling, and public transit service (Phillips, Karachepone, and Landis 2001; Kittleson \& Associates 2003a and 2003b; Litman 2005; Victoria Transport Policy Institute 2006). The Florida Department of Transportation (2002) developed the LOSPLAN computer program to automate these calculations.

Real-time transit vehicle arrival signs reduce perceived wait times by approximately 20 percent. These signs also reduce unit costs of the time spent waiting because passengers experience less stress and are better able to organize their trips. A 20 percent savings therefore represents the lower bound value of cost savings from such systems, provided that the information is easy to access and reliable. 


\section{Table 6. Recommended Travel Time Values}

\begin{tabular}{|l|r|r|r|r|r|r|r|}
\hline \multicolumn{1}{|c|}{ Category } & LOS A-C & LOS D & LOS E & LOS F & \multicolumn{3}{c|}{ Waiting } \\
\hline & & & & & Good & Average & Poor \\
\hline Commercial vehicle driver & $120 \%$ & $137 \%$ & $154 \%$ & $170 \%$ & & $170 \%$ & \\
\hline Commercial vehicle passenger & $120 \%$ & $132 \%$ & $144 \%$ & $155 \%$ & & $155 \%$ & \\
\hline City bus driver & $156 \%$ & $156 \%$ & $156 \%$ & $156 \%$ & & $156 \%$ & \\
\hline Personal vehicle driver & $50 \%$ & $67 \%$ & $84 \%$ & $100 \%$ & & $100 \%$ & \\
\hline Adult car passenger & $35 \%$ & $47 \%$ & $58 \%$ & $70 \%$ & & $70 \%$ & \\
\hline Adult transit passenger-seated & $35 \%$ & $47 \%$ & $58 \%$ & $70 \%$ & $35 \%$ & $50 \%$ & $125 \%$ \\
\hline Adult transit passenger-standing & $50 \%$ & $67 \%$ & $83 \%$ & $100 \%$ & $50 \%$ & $70 \%$ & $175 \%$ \\
\hline Child (<16 years)-seated & $25 \%$ & $33 \%$ & $42 \%$ & $50 \%$ & $25 \%$ & $50 \%$ & $125 \%$ \\
\hline Child (<16 years)-standing & $35 \%$ & $46 \%$ & $60 \%$ & $66 \%$ & $50 \%$ & $70 \%$ & $175 \%$ \\
\hline Pedestrians and cyclists & $50 \%$ & $67 \%$ & $84 \%$ & $100 \%$ & $50 \%$ & $100 \%$ & $200 \%$ \\
\hline Transit transfer premium & & & & & $5-\mathrm{min}$. & $10-\mathrm{min}$. & $15-\mathrm{min}$. \\
\hline
\end{tabular}

Source: Based on Waters 1992; Litman 2006.

Table 7 describes how to value the travel time savings of various types of transit service improvements. Such improvements can be particularly effective at shifting travel from automobile to transit if implemented in conjunction with other incentives such as commute trip reduction programs, parking cash-out, and marketing programs (Victoria Transport Policy Institute 2006).

\section{Table 7. Valuing Service Improvements}

\begin{tabular}{|l|l|}
\hline \multicolumn{1}{|c|}{ Improvement } & \multicolumn{1}{c|}{ Methodology } \\
\hline Faster travel & Travel time savings. \\
\hline Reduced crowding & Reduce time unit costs from high to average. \\
\hline More comfortable vehicles & Reduce in-vehicle time unit costs. \\
\hline Improved waiting conditions & Reduce the high time unit costs typically assigned to waiting. \\
\hline Improved walking conditions & Reduce the high time unit costs typically assigned to walking. \\
\hline Improved coverage area & Reduced walking travel time. \\
\hline Real-time arrival information & Reduce waiting time unit costs. \\
\hline Faster vehicle loading & Reduce wait and travel time costs. \\
\hline More frequent service & Reduce wait time costs. \\
\hline Reduced transfers & Eliminate transfer premium. \\
\hline Increased travel reliability & Reduce the high time unit costs assigned to unpredictable delays. \\
\hline Improved user information & Surveys to determine their value and impacts on ridership. \\
\hline Improved status & Surveys to determine their value and impacts on ridership. \\
\hline
\end{tabular}

\section{Travel Impacts}

Many examples exist of specific service improvements that increase transit ridership and reduce automobile travel (Evans 2004; Wall and McDonald, 2007). Discretionary transit users (people who have the option of driving) tend to be partic- 
ularly sensitive to comfort and convenience improvements (Phillips, Karachepone, and Landis 2001; Litman 2004; DfT 2006).

Transport modelers use generalized cost (total monetary and time costs) coefficients to predict how changes in vehicle operating costs, fares, and travel speeds affect travel behavior. The Transportation Research Laboratory (2004) calculates generalized cost elasticities of -0.4 to -1.7 for urban bus transit, -1.85 for London underground, and -0.6 to -2.0 for rail transport. Dowling Associates (2005) estimate that in Portland, Oregon, the elasticity of transit travel with respect to transit travel time is -0.129 , and the cross elasticity with car travel is 0.036 , meaning that a 10 percent reduction in transit travel time increases transit ridership by 1.29 percent and reduces automobile travel by 0.36 percent. Such elasticities tend to be highly variable, depending on specific demographic and geographic factors. Additional analysis is therefore needed to calibrate the impacts of transit service quality improvements on transit ridership and automobile travel in specific situations.

The elasticity of transit use with respect to service frequency (called a headway elasticity) averages about 0.5 , meaning that each 1 percent increase in transit service frequency increases ridership by 0.5 percent. This can be used to evaluate how reductions in waiting time unit costs are likely to affect ridership.

Currently, public transit is usually supplied with low service quality and fares to provide basic mobility for physically, economically, and socially disadvantaged people. Because most public transit service relies on direct public financial subsidies (unlike automobile travel, which relies on more indirect subsidies, such as the value of public lands devoted to road rights-of-way, free parking provided by governments and businesses, and external accident risk and pollution costs), public officials are reluctant to fund transit service improvements that may be considered excessive and wasteful.

As a result, transit fails to satisfy the demands of travelers willing to pay more for higher service quality. Market studies indicate that a portion of current automobile users will shift to transit if the service is comfortable and convenient (Project for Public Spaces and Multisystems 1999; TranSystems Corporation 2005), and are willing to pay higher fares. Where public transit offers basic quality service with low fares, it is used mainly by transit-dependent people, typically representing 5 to 10 percent of its potential market. However, where service quality is high (comfortable vehicles and stations, reliable and frequent service, walkable neighborhoods, etc.), a significant portion of discretionary travelers (people who could drive) will choose transit. 


\section{Example}

Table 8 summarizes the cost reductions that result from improving the convenience and comfort of a transit trip from LOS E to LOS C by improvements such as adding sidewalks and attractive bus stop shelters, and providing seats in vehicles. As a result, the generalized cost of the trip declines 41 percent, from $\$ 14.66$ to $\$ 6.69$, compared with $\$ 10.14$ for an automobile trip on the same corridor. Such improvements reduce the ratio of transit to automobile costs from 145 percent down to 86 percent. This represents the upper bound of cost savings from comfort and convenience improvements alone, since not all transit trips require transfers or involve travel on crowded vehicles.

\section{Table 8. Travel Time Cost Reductions from Service Quality Improvements}

\begin{tabular}{|l|r|r|r|r|r|r|r|r|r|}
\hline & Walk & Wait & $\begin{array}{c}\text { In } \\
\text { Vehicle }\end{array}$ & Transfer & $\begin{array}{c}\text { In } \\
\text { Vehicle }\end{array}$ & Walk & Total & Fare & $\begin{array}{c}\text { Generalized } \\
\text { Cost }\end{array}$ \\
\hline Transit-Current & & & & & & & & & \\
\hline Minutes & 5 & 10 & 20 & 5 & 15 & 5 & 60 & & \\
\hline LOS rating & $\mathrm{E}$ & $\mathrm{E}$ & $\mathrm{E}$ & $\mathrm{E}$ & $\mathrm{E}$ & $\mathrm{E}$ & & & \\
\hline Portion of wages & $84 \%$ & $70 \%$ & $70 \%$ & $175 \%$ & $70 \%$ & $84 \%$ & & & \\
\hline Travel time costs & $\$ 1.05$ & $\$ 1.75$ & $\$ 3.50$ & $\$ 2.19$ & $\$ 2.63$ & $\$ 1.05$ & $\$ 12.16$ & $\$ 2.50$ & $\$ 14.66$ \\
\hline Transit-Improved & & & & & & & & & \\
\hline Minutes & 5 & 10 & 20 & 5 & 15 & 5 & 60 & & \\
\hline LOS rating & $\mathrm{C}$ & $\mathrm{C}$ & $\mathrm{C}$ & $\mathrm{C}$ & $\mathrm{C}$ & $\mathrm{C}$ & & & \\
\hline Portion of wages & $50 \%$ & $50 \%$ & $35 \%$ & $50 \%$ & $35 \%$ & $50 \%$ & & & \\
\hline Travel time costs & $\$ 0.63$ & $\$ 1.25$ & $\$ 1.75$ & $\$ 0.63$ & $\$ 1.31$ & $\$ 0.63$ & $\$ 6.19$ & $\$ 2.50$ & $\$ 8.69$ \\
\hline Difference & $\$ 0.43$ & $\$ 0.50$ & $\$ 1.75$ & $\$ 1.56$ & $\$ 1.31$ & $\$ 0.43$ & $\$ 5.98$ & $\$ 0.00$ & $\$ 5.98$ \\
\hline Percent change & $40 \%$ & $29 \%$ & $50 \%$ & $71 \%$ & $50 \%$ & $40 \%$ & $49 \%$ & $0 \%$ & $41 \%$ \\
\hline Automobile trip & & & & & & & & & \\
\hline Minutes & 1 & 0 & 30 & 0 & 0 & 3 & 34 & & \\
\hline LOS rating & $\mathrm{E}$ & $\mathrm{E}$ & $\mathrm{E}$ & $\mathrm{E}$ & $\mathrm{E}$ & $\mathrm{E}$ & & & \\
\hline Portion of wages & $84 \%$ & $0 \%$ & $84 \%$ & $0 \%$ & $84 \%$ & $84 \%$ & & & \\
\hline Travel time costs & $\$ 0.21$ & $\$ 0.00$ & $\$ 6.30$ & $\$ 0.00$ & $\$ 0.00$ & $\$ 0.63$ & $\$ 7.14$ & $\$ 3.00$ & $\$ 10.14$ \\
\hline Transit-current/auto & & & & & & & & & $145 \%$ \\
\hline Transit-improved/auto & & & & & & & & & $86 \%$ \\
\hline
\end{tabular}

Improvements of this magnitude should increase transit ridership by about 20 percent, assuming an elasticity of transit travel to generalized costs of -0.5 , about half of which would probably substitute for automobile travel. For example, an urban corridor has 12,000 total daily trips, of which 2,000 are by transit, half of which occur during peak periods. Table 9 illustrates the benefits from improving transit service $L O S$ from $E$ to $C$. These benefits include travel time cost reductions to current transit users (off-peak traveler benefits include no in-vehicle benefits, since these consist largely of reduced crowding, which is a peak-period problem), consumer surplus gains to travelers who shift mode (calculated by dividing monetized unit benefits by two, based on the rule-of-half), and reduced external costs (traffic congestion, parking subsidies, and accident risk) from reduced driving, 
estimated at $\$ 5.00$ per trip during peak periods and $\$ 2.00$ during off-peak periods (Litman 2005). The results indicate that these improvements would provide benefits that average more than $\$ 10,000$ per day, or more than $\$ 350,000$ annually.

Table 9. Monetized Benefits from Service Quality Improvements

\begin{tabular}{|l|r|r|r|}
\hline \multicolumn{1}{|c|}{ Travel Changes } & \multicolumn{1}{c|}{$\begin{array}{c}\text { Unit } \\
\text { Number }\end{array}$} & $\begin{array}{c}\text { Total } \\
\text { Benefits }\end{array}$ & $\begin{array}{r}\text { Benefits } \\
\hline \text { Peak-period riders }\end{array}$ \\
\hline Off-peak riders & 1,000 & $\$ 5.98$ & $\$ 5,980$ \\
\hline New peak riders & 200 & $\$ 2.92$ & $\$ 2,920$ \\
\hline New off-peak riders & 200 & $\$ 1.49$ & $\$ 598$ \\
\hline Reduced peak automobile trips & 100 & $\$ 5.00$ & $\$ 292$ \\
\hline Reduced off-peak automobile trips & 100 & $\$ 2.00$ & $\$ 200$ \\
\hline Total & & & $\$ 10,490$ \\
\hline
\end{tabular}

Although vehicle traffic reductions may appear small (about 2\%), these service quality improvements can be implemented with other mode shift incentives, such as improved transit speeds, fare reductions, parking pricing, and commute trip reduction programs to achieve additional travel impacts and benefits (Victoria Transport Policy Institute 2006). These strategies tend to be synergistic, resulting in larger total benefits when implemented together than the sum of their individual impacts.

This illustrates how convenience and comfort improvements can significantly reduce travel time costs and provide benefits that are virtually invisible to most current transportation economic evaluation models.

\section{Conclusions}

There are many possible ways to improve transit service quality, including reduced crowding, increased service frequency, nicer waiting areas, and better user information. Current transport evaluation methods tend to focus on quantitative factors such as speed and price, and undervalue qualitative factors such as comfort, convenience and reliability. As a result, cost-effective transit improvement strategies are overlooked and undervalued, resulting in underinvestment in transit service quality improvements, making transit less attractive relative to automobile travel. 
Service quality improvements that reduce travel time unit costs (cents per minute or dollars per hour) provide benefits comparable to speed improvement that reduce total travel time. For example, a service quality improvement that reduces travel time unit costs by 20 percent provides benefits equivalent to an operational improvement that increases travel speeds by 20 percent. Techniques described in this article allow service quality to be incorporated into transport planning by adjusting travel time unit costs to reflect convenience and comfort factors. The values recommended in this article can be used as defaults, although they should be calibrated for specific conditions.

This analysis indicates that with high service quality, transit travel unit time costs are lower than for driving. If service is comfortable and convenient, many people will choose transit rather than driving for some trips, even if it takes somewhat more time, since transit travel is less stressful and passengers can rest or work while traveling. However, transit is often inconvenient and uncomfortable, resulting in unit travel time costs higher than driving, which reduces transit ridership.

In a modern, affluent society consumers are accustomed to high quality goods and services. Most travelers place a high value on comfort, convenience, and reliability. Motorists are able to express these values by paying extra for more luxurious vehicles, more convenient parking, and sometimes higher quality toll roads. In contrast, individual transit passengers are generally unable to purchase higher quality service. As a result, transit does not satisfy travelers willing to pay extra for higher service quality - so they generally shift to driving. Ultimately everybody loses, since consumer demand is unmet, transit ridership declines, transit becomes stigmatized, and traffic problems increase.

This is actually good news because it indicates that there are many cost-effective ways to improve transit service quality and increase ridership that tend to be overlooked. Many transit comfort and convenience improvements are relatively inexpensive and provide additional benefits such as improved walking conditions, improved mobility for nondrivers, and support for more compact, smart growth development.

With better evaluation techniques planners can identify policies and programs that more effectively respond to consumer needs and preferences, including transit service improvements. 


\section{Acknowledgments}

This research was supported by TransLink, the Vancouver, BC regional transport agency. Special thanks to Neil Douglas of Douglas Economics for generously sharing information.

\section{References}

Brundell-Freij, Karin. 2006. User benefits and time in road investment and maintenance: The role of speed choice and driving comfort. Transportation Research Board Annual Meeting. Available at www.mdt.mt.gov/research/docs/trb_cd/ Files/06-0158.pdf.

Clty-VITAlity-Sustainability. 2006. Provision of real time passenger information. www.civitas-initiative.org/measure_sheet.phtml?lan=en\&id $=271$.

Cohan, Harry, and Frank Southworth. 1999. On the measurement and valuation of travel time variability due to incidents on freeways. Journal of Transportation and Statistics (December): 123-131.

DfT. 2006. Transport analysis guidance. Integrated Transport Economics and Appraisal, Department for Transport (www.webtag.org.uk/index.htm).

Douglas Economics. 2004. Value of rail travel time. RailCorp (www.railcorp.info).

Douglas Economics. 2006. Value and demand effect of rail service attributes. RailCorp. Contact George.Karpouzis@railcorp.nsw.gov.au to request document.

Dowling Associates. 2005. Predicting air quality effects of traffic flow improvements: Final report and user guide. NCHRP Report 535, Transportation Research Board.

Dziekan, Katrin, and Arjan Vermeulen. 2006. Psychological effects of and design preferences for real-time information displays. Journal of Public Transportation 9 (1): 71-89.

Evans, John E. 2004. Transit scheduling and frequency. TCRP Report 95, Transportation Research Board. Available at http://onlinepubs.trb.org/onlinepubs/tcrp/ tcrp_rpt_95c9.pdf.

Florida Department of Transportation. 2002. LOSPLAN Software. www.dot.state. fl.us/Planning/systems/sm/los/los_sw2.htm. 
Fruin, John J. 1971. Pedestrian planning \& design. New York: Metropolitan Association of Urban Designers and Environmental Planners.

Hensher, David, Peter Stopher, and Philip Bullock. 2003. Service quality-Developing a service quality index in the provision of commercial bus contracts. Transportation Research A 37 (6): 499-517.

Horowitz, Alan J., and Dennis J. Zlosel. 0981. Transfer penalties: Another look at transit riders' reluctance to transfer. Transportation 10 (3): 279-282.

Infopolis 2 Consortium. 2000. Inventory: At-stop display. Passenger Information on Public Transport (www.ul.ie/ infopolis and www.ul.ie/ infopolis/existing/stopdisp.html).

Kittleson \& Associates. 2003a. Transit capacity and quality of service manual. Web document 100, TCRP, Transportation Research Board. Available at www.trb. org/news/blurb_detail.asp?id=2326.

Kittleson \& Associates. 2003b. Guidebook for developing a transit performancemeasurement system, Web document 88, TCRP, Transportation Research Board. Available at www.trb.org/news/blurb_detail.asp?id=1120.

$\mathrm{Li}$, Yuen-wah. 2003. Evaluating the urban commute experience: A time perception approach. Journal of Public Transportation 6 (4): 41-67. Available at www.nctr. usf.edu/jpt/pdf/JPT\%206-4\%20Li.pdf.

Litman, Todd. 2004. Transit price elasticities and cross-elasticities. Journal of Public Transportation 7 (2): 37-58. Updated version available at www.vtpi.org/tranelas.pdf.

Litman, Todd. 2005. Evaluating public transit benefits and costs. Victoria Transport Policy Institute. Available at www.vtpi.org/tranben.pdf.

Litman, Todd. 2006. Travel time. Transportation Cost and Benefit Analysis. Victoria Transport Policy Institute. Available at www.vtpi.org/tca/tca0502.pdf.

Litman, Todd. 2007. Valuing transit service quality improvements: Considering comfort and convenience in transport project evaluation. Victoria Transport Policy Institute (www.vtpi.org).

Lyons, Glenn, Juliet Jain, and David Holley. 2007. The use of travel time by rail passengers in Great Britain. Transportation Research A 41 (1): 107-120. 
Mackie, P., et al. 2003. Values of travel time savings in the UK. Institute for Transport Studies, University of Leeds (www.its.leeds.ac.uk), U.K. Department for Transport (www.dft.gov.uk/stellent/groups/dft_econappr/documents/page/ dft_econappr_610340.hcsp).

Mokhtarian, Patricia L. 2005. Transportation research-special issue: The positive utility of travel 39A (2-3).

Novaco, Raymond, and Cheryl Collier. 1994. Commuting stress, ridesharing, and gender: Analysis from the 1993 state of the commute study in Southern California, UCTC 208.

Passenger Demand Forecasting Council. 2002. Passenger demand forecasting handbook www.atoc.org/RPDFS/index.asp.

Phillips, Rhonda, John Karachepone, and Bruce Landis. 2001. Multi-modal quality of service project. Florida Department of Transportation.

Pratt, Richard H. 1999. Traveler response to transportation system changes, interim handbook. TCRP Web Document 12, Transportation Research Board. Available at www.trb.org/TRBNet/ProjectDisplay.asp?ProjectID=1034.

Pratt, Richard, and John Evans. 2004. Bus routing and coverage: Traveler response to transport system changes, Chapter 10. Report 95, TCRP, Transportation Research Board. Available at http://gulliver.trb.org/publications/tcrp/tcrp_ rpt_95c11.pdf.

Project for Public Spaces and Multisystems. 1999. The role of transit amenities and vehicle characteristics in building transit ridership. TCRP Report 46, Transportation Research Board.

Small, Kenneth, et al. 1999. Valuation of travel-time savings and predictability in congested conditions for highway user-cost estimation. NCHRP 431, Transportation Research Board.

TranSystems Corporation. 2005. Elements needed to create high ridership transit systems: Interim guidebook. Transportation Research Board, TCRP Web Document 32. Available at http://trb.org/publications/tcrp/tcrp_webdoc_32.pdf.

Transportation Research Laboratory. 2004. The demand for public transit: A practical guide. Report TRL 593. Available at www.demandforpublictransport. co.uk. 
Turnbull, Katherine F., and Richard H. Pratt. 2003. Transit information and promotion: Traveler response to transport system changes, Chapter 11. TCRP 95; Transportation Research Board. Available at http://onlinepubs.trb.org/ onlinepubs/tcrp/tcrp_rpt_95c11.pdf.

Victoria Transport Policy Institute. 2006. Online TDM Encyclopedia (www.vtpi. org).

Wall, Graham, and Mike McDonald. 2007. Improving bus service quality and information in Winchester. Transport Policy 14 (2): 165-179.

Wardman, Mark. 2004. Public transport values of time. Transport Policy 11 (4): 363-377.

Waters, William. 1992. Value of time savings for the economic evaluation of highway investments in British Columbia. BC Ministry of Transportation (www.th.gov. bc.ca/publications/repopubs.htm).

Wener, Richard, Gary W. Evans, and Jerome Lutin. 2006. Leave the driving to them: Comparing stress of car and train commuters. American Public Transportation Association (www.apta.com/passenger_transport/thisweek/documents/ driving_stress.pdf).

\section{About the Author}

TODD LiTMAN (litman@vtpi.org) is founder and executive director of the Victoria Transport Policy Institute, an independent research organization dedicated to developing innovative solutions to transport problems. His work helps to expand the range of impacts and options considered in transportation decision-making, improve evaluation methods, and make specialized technical concepts accessible to a larger audience. His research is used worldwide in transport planning and policy analysis.

Mr. Litman has worked on numerous studies that evaluate transportation costs, benefits, and innovations. He authored the Online TDM Encyclopedia, a comprehensive Internet resource for identifying and evaluating mobility management strategies; Transportation Cost and Benefit Analysis: Techniques, Estimates and Implications, a comprehensive study that provides cost and benefit information in an easy-to-apply format; and the study Rail Transit In America: Comprehensive Evaluation of Benefits. 
Mr. Litman is active in several professional organizations, including the Institute of Transportation Engineers and the Transportation Research Board. He currently chairs the TRB Sustainable Transportation Indicators Subcommittee. He is a member of the Editorial Advisory Board of Transportation Research A. 